\title{
The Legacy of the King James Bible: Celebrating 400 Years of the Most Influential English Trans- lation, by Leland Ryken
}

Wheaton: Crossway, 20II | 265 pages | ISBN: 978-I-4335I388-6 (softback) \$ I 5.99

The reference librarian of our new seminary library, Mary Robison, searched WorldCat and OCLC for

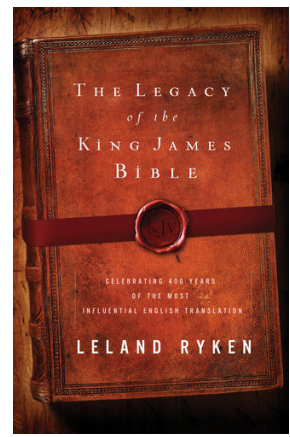
books about the King James Bible (KJB) written in English between 2009 and $201 \mathrm{I}$, and found that thirty-six are listed. Of those, six were published in $20 \mathrm{II}$ and eight in $20 \mathrm{IO}$. This is one of the $20 \mathrm{II}$ books, by Wheaton College English Professor Leland Ryken. It is an encomium to the I6I I King James translation. He says that the KJB is "demonstrably the greatest English Bible ever." He grew up listening to it. As a child he heard readings from the KJB at every meal and twice a day on Sundays. He writes this book to tell the story of what it is and how it has influenced the English-speaking world.

Professor Ryken calls the translators of the KJB "the best of the best" (53) and their work "the most accurate bible that had appeared" (62). But what does "most accurate" mean? We might agree that the KJB evidences superior literary qualities and that it has had "unparalleled influence in the English-speaking world" (98). However, as Ryken acknowledges, the KJB is based on manuscripts scholars today know to be inferior. But he calls the $\mathrm{KJB}$ superior because it is better than several modern translations adopting the principle of dynamic equivalence. So "most accurate" does not mean "based on the best manuscripts" but is the result of comparing the KJB to some modern translations based on dynamic equivalence. To call the KJB "most accurate" by comparison with several modern translations that employ a different philosophy of translation seems odd if not disingenuous. It 
is like trying to use a barometer to measure volume. Why not compare the KJB to more formal modern translations such as those of Everett Fox for the Hebrew Bible, or Robert Alter for the Psalms? Here I note that Ryken never uses the (gender-neutral) New Revised Standard Version, so the reservoir of translations from which the book draws is restricted for reasons that are not explained. The New Revised Standard Version is mentioned only to be dismissed, since its adherence to the KJB is "halfhearted" (73). Only the New King James, the Revised Standard Version, and the English Standard Version stand in the KJB tradition. Ryken's book is written for people who share his opinion about the New Revised Standard Version.

What might "accurate" mean in general? Does it mean faithful reproduction of the Greek and Hebrew language of the source text? Or does it mean faithful rendition of the source text so as to be understood by modern readers? Ryken seems to favor a more literal or word-for word rendering of the source texts in majestic prose. A paraphrase translation of the KJB, or one of formal equivalence, or one of dynamic equivalence could each justifiably be called accurate, even if each had a different understanding of the word "accurate" based on method or usage. All translations have strengths and weaknesses. In 2003 the scholar David Daniell, an expert on the Bible translator William Tyndale, asserted that the Geneva Bible is superior to the KJB: "The replacement from I6I I of the remarkable, accurate, informative, forward-looking Geneva Bible even at the time of its greatest growth and power with the backward looking, increasingly Latinist, often baldly unhelpful KJB is one of the tragedies of our culture." Ryken does not assess the Geneva Bible; he simply describes it as "a great forerunner to the King James" to which "it eventually gave way." It is not just that the KJB relies on inferior manuscripts ( I $3-I 4_{4}$, 64-66): it is that scholars today have many more manuscripts and they are much older. And the alternative to the KJB is not several modern translations employing principles of dynamic equivalence, but rather a balanced assessment of modern translations using varying principles of translation together with (reconstructed) Hebrew and Greek texts.

Ryken's book is divided into four parts: I) The KJB in its own day, 2) the $\mathrm{KJB}$ in history, 3) the KJB as a literary masterpiece, and 4) the literary influence of the KJB. It is safe to say that the second half of the book is more reliable than the first given the author's expertise in sixteenth- and seventeenth-century literature. Thus, readers may encounter strange statements about the text of the Bible here and there: “The prologue to John's gospel echoes a famous hymn to Zeus that the ancient Greeks had sung to 
Zeus for centuries by the time John wrote it" (I 54). Ryken states that Tyndale "died a martyr for translating the Bible" (24). While many people share this opinion, it seems untrue. Transcripts from Tyndale's trial indicate that he was arrested on the grounds of his Lutheran heresy.

In his professional element for the second half of the book, Ryken's examination of the literary influence of the KJB is interesting. But it is onedimensional: the influence from the KJB to the artist is stated flatly. For instance, Ryken argues that the point of departure for George Herbert's poem "Love iii" (I 86-7) "was almost certainly Luke I 2:37." Others observe that Herbert may be equally, if not more influenced by the temptation scene in Milton's Paradise Regained, book 2 in which Satan entices Jesus three times to an extravagant if decadent banquet through an invitation "to sit and eat" $(2.336,368,377)$, echoed and transformed by Herbert in the poem's last line: "So I did sit and eat."

In the same vein, it is not always apparent if the stream of KJB references are directly attributable to the KJB or simply evidence of the power of the translation. For example, most modern English phrases that sound as if they might be from the KJB do not originate in the KJB at all but are found in Tyndale or the Bishops' Bible of I 568 or Wycliffe's translation or one of the other major versions of the sixteenth century. A few phrases, however, like "how are the mighty fallen," "the root of the matter," and "a thorn in the flesh" are directly attributable to the KJB.

What the KJB did was put before the English-speaking world pithy biblical phrases that were adopted by public discourse to the extent that they pass into contemporary expression. We cannot say that such phrases as "to everything there is a season" and "my brother's keeper" are directly attributable to the KJB wherever they occur. They are simply part of public discourse.

In exploring the afterlife of the $\mathrm{KJB}$, why not consider more wide-ranging connections and associations between for example the KJB and other religious texts such as the Bhagavad-Gita? The Gita, written in Sanskrit, is part of the writings of Hinduism written somewhere between the fourth-fifth centuries BCE and the third century CE. The received version is 700 verses in I 8 chapters composed in a beautiful language with its own cadences. British scholars in India first translated the Gita in 1785. In 1962, the Penguin Classic Edition of the Gita published in English by Juan Mascaro, was deeply influenced by the shape and forms of the KJB, e.g., Gita I I:36, "I will be glad and rejoice in thee, I will sing praise to thy name, I will be glad in God most High." Compare Psalm 9:2 with the same phrases. 
The book has a few typographical errors: "And a man shall be [add: as] an hiding place from the wind, and a covert from the tempest" (96; Isaiah 32:2); "holy men [add: of God] spake as they were moved by the Holy Ghost" ( I I 2; 2 Peter I:2I); "whist [should be: wist] ye not that I must be about my Father's business?" (I I 3; Luke 2:49); the citation of Luke I2:37 (I 87) has too many commas. Finally, in a book that praises the KJB, why not cite the text using the text's own distinction between italics and roman type?

Deirdre Good

General Theological Seminary 